\title{
CORRELATION OF IGNITION DELAY FOR VARIOUS METHANE BASED FUEL BLENDS
}

\section{VOJTËCH KLÍR, VIT BERÁNEK}

Josef Božek Research Centre of Engine and Automotive Engineering, Technická 4, 16607 Praha 6, Czech Republic, Tel.: +420 224351827, E-mail: vojtech.klir@fs.cvut.cz

\begin{abstract}
SHRNUTí
Účinnost spalovacích motorů je limitována zejména výskytem klepání. Jistý kompromis mezi zamezením výskytu tohoto nežádoucího režimu spalování a príjatelnou hodnotou účinnosti spalovacího motoru je provozování motoru v oblastech velmi blízkých mezi klepání. Poloha této hraniční oblasti je zároveň ovlivněna složením použitého palivo, které může mít různou deklarovanou odolnost vǔči klepání. Popis výskytu klepání je jednou z nejdůležitějších okolností, která nesmí být při návrhu motoru opomenuta. Již v počátečných stadiích vývoje motoru je samozřejmé žádoucí získat první poznatky o možném výskytu klepání s využitím matematického modelu. Přispěvek popisuje model klepání založený na výpočtu vyčerpaného průtahu vznícení. Vliv rozdílného složení paliva je popsán pomocí metanového čísla, které je zahrnuto do vztahu určeného pro výpočet prodlevy vznícení.
\end{abstract}

KLíČOVÁ SLOVA: KLEPÁNÍ, PRŮTAH VZNÍCENII, PLYNNÁ PALIVA, METANOVÉ ČíSLO

\begin{abstract}
It is very well known that the efficiency of an SI engine is limited by knock occurrence. As a compromise between knocking combustion avoidance and an accepted level of efficiency, an engine is typically operated at very close to the knocking boundary. However, the position of an engine knocking boundary is shifted if the fuel composition changes. The description of this abnormal combustion is therefore a challenging task in engine development. There is a requirement to use a model description in the early stage of engine design. The objective of this paper is to introduce a knock model based on the calculation of exhausted auto-ignition delay. A term containing the methane number of the relevant fuel blend was incorporated into a formula describing the ignition delay. This formula is applicable for prediction of knock occurrence during engine operation on various fuel blends.
\end{abstract}

KEYWORDS: ENGINE KNOCK, IGNITION DELAY, METHANE BASED FUELS, METHANE NUMBER

\section{INTRODUCTION}

Methane based fuel blends have been seen as an alternative fuel for spark ignition engines due to their lower $\mathrm{CO}_{2}$ emissions when compared to standard gasoline fuel, as well its availability world-wide. In order to obtain high engine efficiency, modern engines operate very close to regimes with knock occurrence. Due to difficulties and the high cost associated with experimental studies, it is desirable to develop reliable and accurate models to predict the occurrence of engine knock in conditions relevant to the engine operation.

\section{KNOCK PHENOMENA DESCRIPTION}

Knock is an abnormal combustion process occurring in $\mathrm{SI}$ engines. It results in an abnormal auto-ignition of the end gas ahead of the propagating flame front. This phenomenon is characterized by the occurrence of pressure oscillations at a characteristic frequency. The impact of knock depends on its intensity and duration. Detection of this abnormal combustion, and the evaluation of knock intensity is therefore a challenging task. It should be appreciated that the combustion mechanism associated with knock is still not fully understood; however, both experimental and model description methods have been proposed and used for knock phenomena description. 


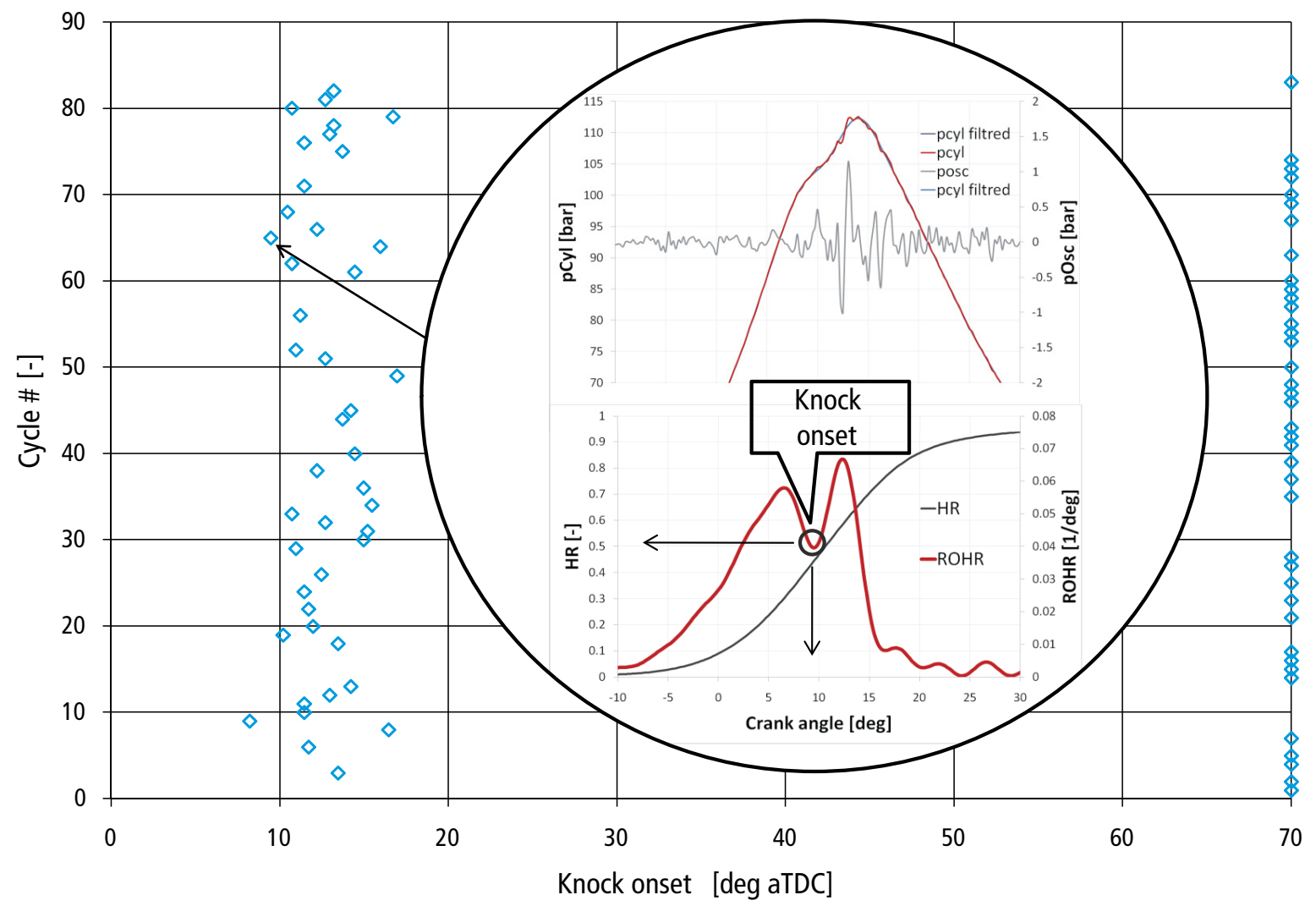

FIGURE 1: Knock phenomena description.

OBRÁZEK 1: Popis výskytu klepání.

\subsection{EXPERIMENTAL METHODS}

Experimental methods investigate the different physical quantities that are influenced by knock occurrence. These methods can be divided into several categories according to the physical quantity they use to detect knock. At the author's workplace knock occurrence and its intensity are identified experimentally by evaluation of oscillation of in-cylinder pressure, and by evaluation of a vibration sensor signal. The first method is then primarily used for off-line evaluation. Knock occurrence and knock intensity are obtained from evaluation of in-cylinder pressure data.

The INTEC [1] program is used for this evaluation. All individual cycles must be browsed in order to record all knock onsets correctly. Figure 1 presents measured knock onsets for one measured point containing approximately 80 individual cycles, and shows the definition of knock onset. Value 70 of knock onset represents cycles where knock didn't occur. The angle resolved patterns in the figure shows the raw pressure trace recorded during a knocking cycle, along with the corresponding filtered signal (cut-off frequency $5 \mathrm{kHz}$ ) and the difference between filtered and unfiltered pressure signal. Knock is usually considered as occurring when the pressure oscillations exceed a predefined threshold value defined by the amplitude of pressure oscillations. Nevertheless, in many cases the ROHR curve provides more exact information about the knock onset position. Knock is then typically described by its starting angle and by the value of normalized heat release at this onset.

The second method - evaluation of vibration sensor signal, is used for on-line monitoring of engine knock. Knock occurrence and intensity was monitored using an AKR unit. This unit processes the signal from a standard knock sensor using discrete Fourier transform with a Digital Signal Processor HW platform. This generates an analog output signal which is dedicated for ignition timing control. The knock intensity is divided into three levels in terms of the output voltage value (0V - Knock Free, 0 2V Light Knock, $>2 \mathrm{~V}$ Heavy Knock). In this case the value of the AKR output is only acquired by a DAQ system. The information about the knock intensity is therefore obtainable in this manner.

\subsection{MODEL METHODS}

The knock model is based on a developed relationship for calculation of the ignition delay and the theory developed by Livengood and $\mathrm{Wu}$ [2]. They proposed that auto-ignition occurs when:

$\int \frac{1}{\tau} d t=1$ 
The parameter $\tau$ is the induction time at the instantaneous temperature and pressure of the mixture. The relationships for induction time usually have the following form:

$\tau=A \cdot p^{-n} \cdot \exp \left(\frac{B}{T}\right)$

Simulations can be performed with different width and depth of accuracy [3]. Knock prediction codes including detailed chemical kinetics have the greatest degree of physicality. These codes are based on the chemical reactions and are very complex. This is why attempts are made to implement an empirical approach based on results from a detailed model. Definition of end-gas temperature is a crucial issue when this kind of model is employed. Angle resolved patterns describing behavior of the working substance during the high pressure part of the working cycle (in-cylinder pressure and temperature of unburned mixture) are used for calculations [4]. These data can be obtained from experimental data or from mathematical simulations. Nevertheless, the endgas temperature must be determined in all cases using an appropriate mathematic model.

Three approaches have been tested to determine the pattern of end-gas temperature. The simplest method for implementation of a two-zone approach is based on the assumption that a locally averaged cylinder charge temperature represents a weighted average of temperatures of both burnt and unburned zones, whilst the burned fraction is the weighting factor. The unburned zone temperature $T_{u}$ after start of combustion is computed assuming polytropic compression of the unburned charge - two-zone mean temperature model (2ZMTM). The polytropic exponent is then calculated using the relationship developed by Brunt [5]. The OBEH [6] simulation tool involves a routine based on description of the energy balance across the layer which is not influenced by flame. However, it calls for additional parameters (fictive layer thickness - which defines the volume to surface ratio and thermal resistance of the layer). Inputs for the knock model were also obtained from a mathematical model created in the GT-Power simulation tool where a full two-zone model is implemented. Three Pressure Analysis (TPA) was employed in the simulation tool. This procedure uses the experimentally acquired pressure patterns in intake and exhaust manifold as boundary conditions. The measured in-cylinder pattern is used for determination of the Heat Release (HR) curve using a GT-Power routine. Then the in-cylinder pressure and all other relevant quantities are calculated by simulation. The obtained angle-resolved patterns of end-gas temperature were very close together for all the above-mentioned methods in many cases. It is clear that the end-gas temperature pattern plays the key role in knock modeling. It is assumed that the two-zone model provides a reasonable level of accuracy in comparison with calculation time.

\section{EXPERIMENTAL OUTPUTS}

The experiments were simultaneously performed on two turbocharged gas fueled engines: $4 \times \varnothing 102 / 120 \mathrm{~mm}$ and $4 \times \varnothing 102 / 110 \mathrm{~mm}$. Table 1 gives basic information on the engine features. The A712 engine emulates a "low cost" version of current engines with low boost pressure and it is used mainly for preliminary testing. The G432 engine represents the "state of the art" for gas engines with high boost pressure and BMEP. Natural gas was used as a standard fuel. Two additional gaseous components can be delivered during engine running directly into the engine intake manifold upstream of the compressor simultaneously with the delivery of the main gaseous fuel. In this way the composition of the fuel blend can be adjusted within a certain range and even changed while the engine is running continuously.

\begin{tabular}{lcc} 
ENGINE & $\mathrm{A} 712$ & $\mathrm{G} 432$ \\
\hline bore $[\mathrm{mm}]$ & $4 \times 102$ & $4 \times 102$ \\
\hline stroke & 110 & 120 \\
\hline compression ratio & 10 & 12 \\
\hline cylinder head & 2 -valves & 4 -valves \\
\hline turbocharger & uncontrolled & VGT \\
\hline$\lambda$-control & $\begin{array}{c}\lambda=1 \text { (closed loop) } \\
\text { or lean burn }\end{array}$ & $\begin{array}{c}\lambda=1 \text { (closed loop) } \\
\text { or lean burn }\end{array}$ \\
\hline EGR & no & cooled up to $20 \%$ \\
\hline intercooler & not at all & powerful
\end{tabular}

TABLE 1: Tested engines

TABULKA 1: Zkoušené motory

Using common equipment and procedures, the parameters recorded were pressure and temperature of the working substance in various parts of engine manifolds, flows of fuels(s) and air, cooling water temperature in both engine and EGR (if any) cooling systems, engine speed and torque. The feedback signals from all actuators were also acquired and recorded. An additional set of gas analyzers took samples from the engine intake manifold. The analysis outputs were used as computational inputs for determination of EGR rate and/or for verification of the fuel blend composition. Knock occurrence and intensity were monitored using an AKR device. During the whole experimental cycle the angle-resolved patterns of in-cylinder pressures as well as the absolute pressures in both the intake and the exhaust manifold (sensors installed as close to the cylinder as possible) were acquired. 
Approximately 100 operational points were acquired during measurements. They were preprocessed using the TPA procedure and then used as inputs for the knock model. Natural gas and its blends with various additions of propane, carbon dioxide and hydrogen were tested. In order to acquire experimentally the sensitivity of fuel blends to engine adjustment, the sequences of operational regimes were recorded at constant flow for the mentioned three additives. Maximum inflow of propane was limited by knock occurrence at approx $15 \%$ (vol). During operation with the addition of carbon dioxide, knock does not occur and maximum inflow was set above $30 \%$ (vol). During operation with the addition of hydrogen knock also does not occur, the sequences finished with a content of hydrogen in the fuel blend of approx. $25 \%$ (vol).

\section{OPTIMIZATION OF THE KNOCK MODEL}

The basic strategy used for model description of knock phenomenon is based on evaluation of the exhausted part of ignition delay in the end gas zone of the combustion chamber. This algorithm is used due to its simplicity and short computational time in most commercial codes where the knock model is available. Nevertheless, it is clear that codes including detailed chemical kinetics must be used when the highest degree of physicality is required. This is the reason why the results from a detailed kinetics model are implemented in these relationships. A large number of studies have been performed in ignition delay research. Both experimental methods and chemical kinetics have been utilized to study auto-ignition delay phenomena in methane based fuel. Several correlations were established for autoignition time of pure methane [7]. However, in many cases the available correlations do not agree well.

The introduced correlation for ignition delay is based upon the results from a chemical kinetics model. This chemical kinetics model was built using the Chemkin and GRI-Mech mechanism. The reaction mechanism consisting of 53 components and including 325 reactions was used to describe the combustion of methane. The formula for calculation of ignition delay for methane was compiled upon the outputs obtained from this solution using experimental data [8]. The relationship has the form:

$\tau=8,13 \cdot 10^{-4} p^{-1} \exp \left(\frac{18508}{T}\right)$
Preliminary results from the knock model do not show good agreement with experimentally determined regimes for knock occurrence. Since the main interest is to distinguish correctly between knocking and knock free regimes, relationship 3 has been modified. The idea was to minimize the error of the Livengood-Wu integral at the measured knock angle. The least squares method is used to minimize this error. Relationship 4 defines the value to be minimized.

$\sum_{i=1}^{i=n}\left(\int_{t=0}^{t=k n o c k} \frac{1}{8,13 \cdot 10^{-4} p^{-1} \exp \left(\frac{B}{T}\right)}-1\right)^{2}=M I N$

Where $\mathrm{n}$ is the number of cycles to be investigated. The optimization was performed using regimes with varying speed, lambda and engine load. Natural gas was used as a fuel. The inputs were created using measured pressures and simulated end-gas temperature from the two-zone mean temperature model. The cycles on the knocking boundary (knock onset was set very close to the end of the combustion) were used in order to achieve a higher level of plausibility. Equation 4 was minimized only by the value B. It was assumed that the differences between experimental and model results are caused mainly by the method used for determination of the end-gas temperature. The two-zone model is not able to take into account all relevant circumstances. The optimization procedure was created using the $\mathrm{C}++$ programming language.

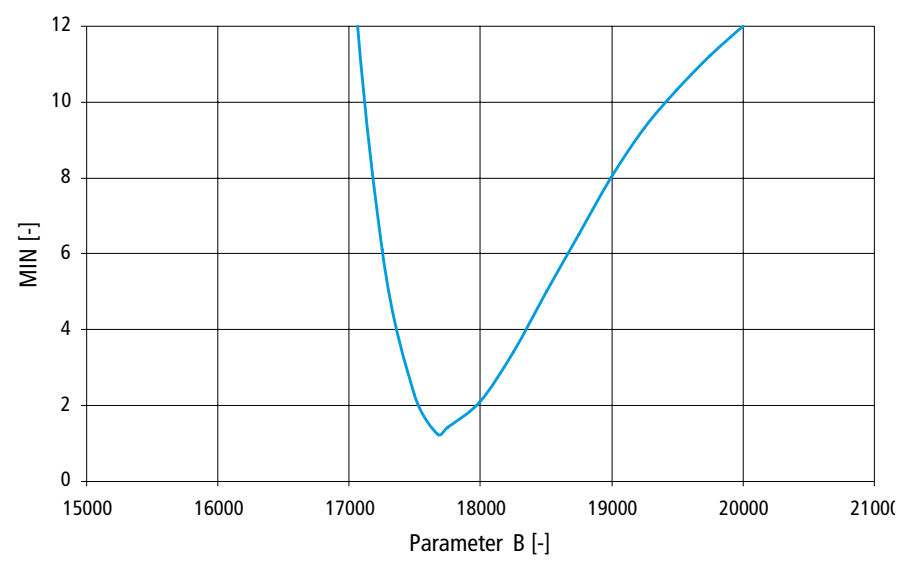

FIGURE 2: The output from optimization procedure for parameter $\mathrm{A}=0.000813$.

OBRÁZEK 2: Výstup z optimalizační procedury pro hodnotu parametru $A=0.000813$. 


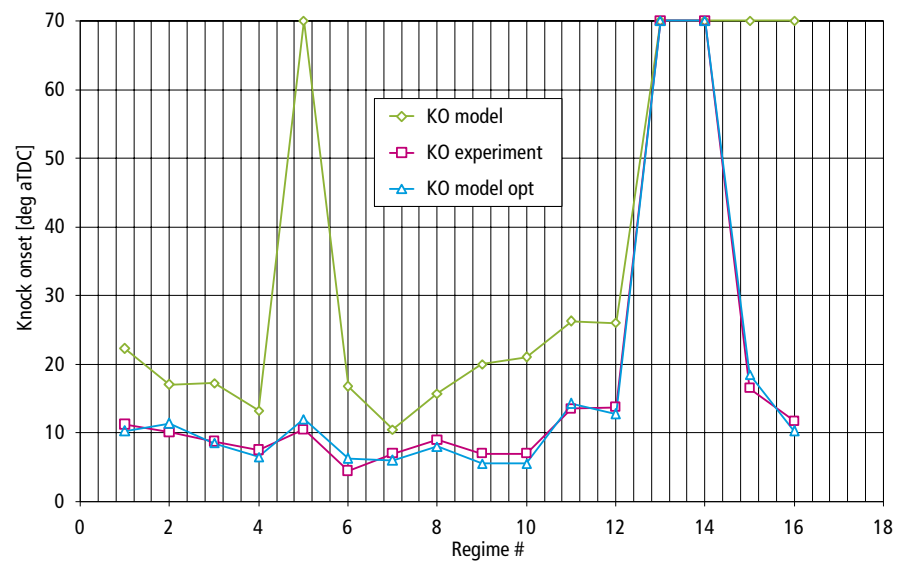

FIGURE 3: Knock model results after the optimization process. OBRÁZEK 3: Výstupy z modelu klepání po optimalizaci.

Figure 2 shows the value of equation 4 when the parameter $B$ varies. Optimization resulted in a value of 17665 for constant B.

$\tau=8,13 \cdot 10^{-4} p^{-1} \exp \left(\frac{17665}{T}\right)$

Figure 3 shows a comparison between simulated and evaluated knock onsets before and after the optimization process. It can clearly be seen that using the optimized value of parameter $B$ brings an improvement in the simulated knock onset when compared to measured data. Providing that the constant $B$ in equation 3 corresponds to the activation energy then it can be concluded that the activation energy needed to initiate the combustion of pure methane is higher than in the case of natural gas. This conclusion is fully consistent with the expected result.

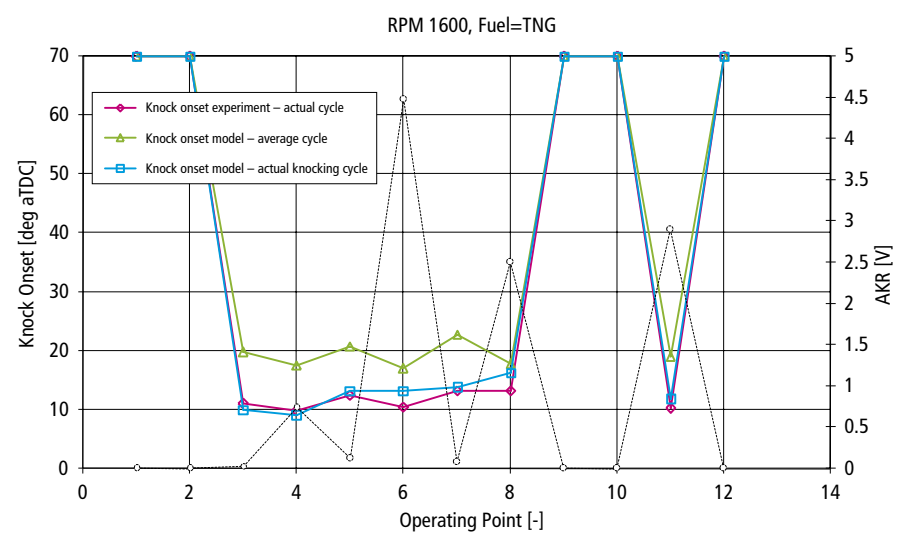

FIGURE 4: Knock model results for average and actual cycles.

OBRÁZEK 4: Výstupy z modelu klepání pro průměrné a okamžité oběhy.
The plausibility of the knock model for an average cycle was studied, as it was time consuming to determine the knock onset position for each knocking cycle and subsequently generate the average cycle compiled only from cycles with knock occurrence. It seems to be beneficial to compile a knock model which is able to predict a regime with occurrence of knock when the average cycle (i.e. averaged from whole record of consecutively acquired cycles) is used. Figure 4 gives the response and shows the predictive ability of the knock model. Knock onsets are compared as they were calculated from the model and determined experimentally (Knock onset $=70^{\circ}$ means a regime without the occurrence of knock). The corresponding knock intensity is described by the plotted AKR output voltage. The record of operational points was evaluated with stepwise changing of VGT stator vanes position (the boost pressure was varying) for a given engine speed, throttle position and ignition timing. The rate of EGR was changed in order to suppress the knocking at a higher boost pressure level. The record containing both regimes with various knock intensity levels and knock free operating points was created in this way. The knock onset is predicted for knocking cycles incorrectly; however, the occurrence of knock is determined correctly. Moreover, from this picture it can be concluded that the knock model is able to predict knock onset very close to experimental results when the knocking cycle is used as an input.

In the next step, effort was dedicated to describing knock occurrence when the fuel composition varies. Currently there is a growing concern about the future of energy supplies. For this reason alternative fuels are being used and developed to complement or maybe replace conventional fuels in the future. Gaseous fuels are typically derived from a variety of feedstock such as natural gas, biomass, waste products and others. This situation introduces variation in fuel composition and the key property for these fuels is their knock tendency. In the case of gaseous fuels, knock resistance is generally defined by the methane number (MN). Therefore to formula 5 for calculation of ignition delay was added a term containing the methane number of the relevant fuel blend in a similar way to which Douad and Eyzat [9] applied the octane number in the case of liquid fuels. In this manner the formula is applicable for the prediction of knock occurrence during engine operation on various fuel blends. The exponent describing the ignition delay time sensitivity on methane number was evaluated from experimental results. The process used for this evaluation was the same as in the first case. The constant A was modified with respect to methane number of natural gas (TNG) $\left(\mathrm{MN}_{\mathrm{TNG}}=94\right)$ before starting the evaluation process. The final relationship has the form: 
$\tau=0.000911 \mathrm{p}^{-1} \exp \left(\frac{17665}{\mathrm{~T}}\right) \cdot\left(\frac{M N}{100}\right)^{1,85}$

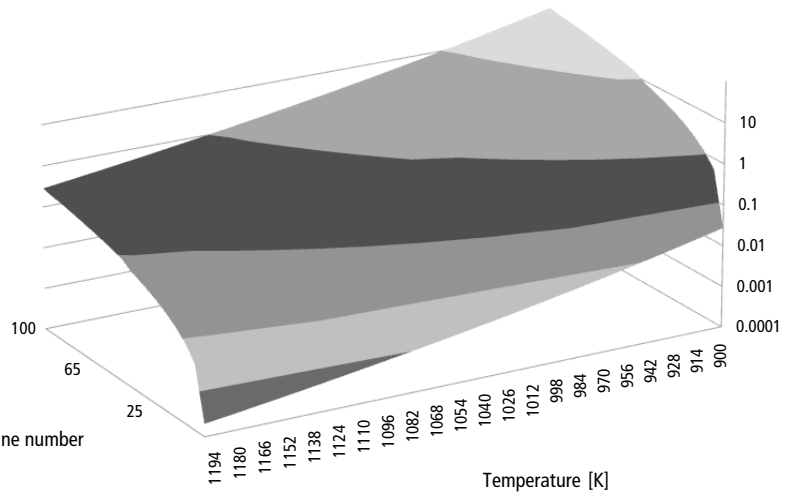

FIGURE 5: Effect of methane number and temperature on ignition delay at a of pressure 80 bar.

OBRÁZEK 5: Závislost času potřebného ke vznícení na metanovém čísle a teplotě při tlaku 80 bar.

Experimental data originating from the combustion of the natural gas blends with various additions of propane, carbon dioxide and hydrogen were included in the evaluation process. Figure 5 illustrates the effect of methane number on the value of ignition delay for a given temperature at a pressure of 80 bar. This result is fully consistent with generally expected trends.

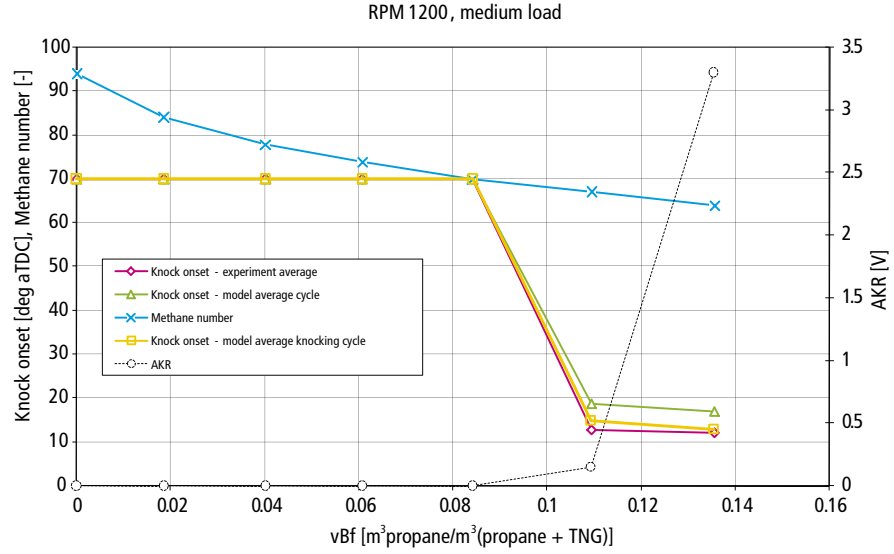

FIGURE 6: Knock model results - addition of propane.

OBRÁZEK 6: Porovnání experimentálních a modelových výsledků v prípadě pridávání propanu.

Figure 6 shows the predictive ability of the knock model when the fuel composition is varying. Knock onsets are compared as they were calculated from the model (based on the average cycle) and determined experimentally (Knock Onset $=70^{\circ}$ means knock-free operation). The corresponding knock intensity is described by the AKR output voltage plot. The sequence of operational points was evaluated with a stepwise increase of propane content when blended with natural gas. The methane number of the fuel blend is also plotted [10]. The knock onset is predicted for knocking cycles incorrectly; however, the occurrence of knock depending on propane content in the blend with natural gas is determined correctly. The correlation between modeled and calculated results is significantly improved when the knock model uses averaged data for knocking cycles. These results are also plotted in Figure 6. It is clear that the model is able to describe knock onset to within four crank angle degrees in this case.

\section{DISCUSSION}

The description of knock phenomena was elaborated by a combination of a phenomenological and causal approach. The theoretical investigations were based upon the results of a chemical kinetics model. The general constants based on experimental data were implemented into the formula used for calculation of ignition delay. Due to the difficulty in determining knock onset from experimental data, the results appear to be very promising. However, the ability of the knock model to predict occurrence of engine knock must be verified in practice. Some limitation can be expected depending on the calibration data used in the simulation. Currently the formula is implemented directly into the engine model [11]. Then the occurrence of engine knock is calculated simultaneously with the simulation of the entire working cycle.

\section{CONCLUSIONS}

A knock model containing a formula describing the ignition delay for various methane based fuels was developed. A term containing the methane number of the given fuel blend was added to this formula. The derived routine is able to determine the occurrence of knock with sufficient accuracy, even if it uses modeled (or averaged from a sequence of experimentally acquired) angle resolved patterns of in-cylinder pressure and temperature in the unburned zone as inputs.

\section{ACKN OWLED GMENT}

The results presented in the article have been obtained within the framework of participation of the author's workplace in the Integrated project InGas Integrated Gas Powertrain Low Emission, $\mathrm{CO}_{2}$ optimized and efficient $\mathrm{CNG}$ engines for passengers cars (PC) and light duty vehicles (LDV) SCS7-GA-2008-218447. 


$\begin{array}{llr}\text { EGR } & \text { Exhaust Gas Recycle } & {[-]} \\ \text { HR } & \text { Heat Release } & {[-]} \\ \text { MN } & \text { Methane Number } & {[-]} \\ \mathrm{p}_{\text {cyl }} & \text { In-cylinder Pressure } & {[\mathrm{bar}]} \\ \mathrm{p}_{\text {osc }} & \text { Pressure Oscillations } & {[\mathrm{bar}]} \\ \text { ROHR } & \text { Rate of Heat Release } & {[1 / \mathrm{deg}]} \\ \mathrm{T} & \text { Temperature of unburned mixture } & {[\mathrm{K}]} \\ \text { TNG } & \text { Transit Natural Gas } & \\ \text { vbf } & \text { Molar Fraction of Propane in Fuel Blend } & {\left[\mathrm{m}^{3} / \mathrm{m}^{3}\right]} \\ \tau & \text { Ignition Delay } & {[\mathrm{s}]}\end{array}$

\section{REFERENCES}

[1] Takáts M. (2000). INTEC In-Cylinder Pressure Recording. [computer software]. Prague: CTU in Prague.

[2] Livengood J.C. \& Wu P.C. (1955). Correlation of Autoignition Phenomenon in Internal Combustion Engines and Rapid Compression Machines: Fifth Symposium (International) on Combustion.

[3] Heywood John B. (1988). Internal Combustion Engines Fundamentals. USA : McGraw-Hill, Inc. ISBN 0-07-028637-X.

[4] Klír V. \& Takáts M. (2010). Description of Knock Onset in SI Turbocharged Gas Engine. Bielsko-Biala : Polish Scientific Society of Combustion Engines. ISSN 0138-0346.

[5] Brunt M. F. J. \& Emtage, A. L. (1998). The Calculation of Heat Release Energy from Engine Cylinder Pressure Data. Detroit : SAE. SAE 981052.

[6] Macek J. OBEH: 0-D Mathematical Model of Combustion Engine [computer software]. Prague: CTU in Prague.

[7] Samuelse S. \& Mc. Donell V. (2003). Correlation of Ignition Delay with Fuel Composition and State for Application to Gas Turbine Combustion. University of California.

[8] Polášek M. \& Hofman K. (2002). Simulation of Knock Invocation in Cylinder of SI Engine. místo neznámé : Konference kateder a pracovišt' spalovacích motorů.

[9] Douaud A. M. \& Eyzat, P. (1978). Four-Octane-Number Method for Predicting the Anti-Knock Beheviour of fuels and Engines. SAE 780080. 